\title{
Aquinas on the Light of Glory
}

\author{
Michael M. Waddell \\ Saint Mary's College (Notre Dame, Indiana, USA) \\ mwaddell@saintmarys.edu
}

\begin{abstract}
In this essay, I examine Thomas Aquinas's doctrine of the light of glory (lumen gloriae). I begin by describing the function of the lumen gloriae in Aquinas's account of cognition and his broader teaching, thereby indicating what is at stake in the success of this doctrine (section two); then I attempt to solve two difficult problems that arise from Aquinas's teaching on the light of glory (sections three and four).

Key words: Aquinas; St. Thomas; lumen gloriae; light of glory; cognition; knowledge; reason; faith; grace; glory; nature; light; beatific vision; beatitude; happiness; neoPlatonism; participation.
\end{abstract}

Recibido:I5-I2-IO. Aceptado:I8-O5-I I 


\section{Resumen}

En este ensayo, examino la doctrina de Tomás de Aquino acerca de la "luz de la gloria" (textitlumen gloriae). Comienzo describiendo la función de la "luz de la gloria" en la propuesta aquiniana de conocimiento y su enseñanza; posteriormente analizo lo que está en juego para que esta doctrina sea exitosa (sección dos); y finalmente, propongo una solución para dos problemas difíciles que subyacen en la enseñanza aquiniana de la "luz de la gloria" (secciones tres y cuatro).

Palabras clave: Tomás de Aquino, lumen gloriae, "luz de la gloria", cognición, conocimiento, razón, fe, gracia, gloria, naturaleza, luz, visión beatífica, beatitud, alegría, neo-platonismo, participación.

\section{Introduction}

As scholars of Thomas Aquinas's thought have become more comfortable with the role of neo-Platonism in Aquinas's metaphysics, it was inevitable that we would also begin to appreciate the ways in which neoPlatonic concepts have influenced Aquinas's teaching on cognition ${ }^{\mathrm{I}}$.

\footnotetext{
${ }^{\mathrm{I}}$ On Aquinas and neo-Platonism, see the classic studies by Louis-Bertrand Geiger, OP: La participation dans la philosophie de saint Thomas d'Aquin, Paris: Vrin I953; Cornelio FABRO: La nozione metafisica di particepazione secondo S. Tommaso d'Aquin, Turin: Società Editrice Internazionale I950; and idem: Participation et causalité selon saint Thomas d'Aquin, Louvain: Publications universitaire de Louvain 196I. More recently, see, for example, Rudi A. te Velde: Participation and Substantiality in Thomas Aquinas, New York: Brill I995; Fran O'Rourke: Pseudo-Dionysius and the Metaphysics of Aquinas, New York: Brill I992; Wayne Hankey: "Aquinas and the Platonists", in The Platonic Tradition in the Middle Ages: A Doxographic Approach, ed. Gersh and Hoenen, New York: de Gruyter 2002, pgs. 279-324; idem: "Pope Leo's Purposes and St. Thomas' Platonism”, Atti dell'VIII Congresso Tomistico Internazionale
} 
Thomas himself describes natural human reason as a participation in the divine light, and notes that grace and glory are superadded to this participation ${ }^{2}$. Some commentators have also begun to note the role that participation plays in Thomas's account of the human modes of knowing. Consider, for example, John Milbank and Catherine Pickstock's description of faith and reason as participation in the divine intellect:

Reason and faith in Aquinas represent only different degrees of intensity of participation in the divine light of illumination and different measures of absolute vision. . . . faith . . . is only higher than reason because it enjoys a deeper participation in the divine reason which is direct intuition or pure intellectual vision ${ }^{3}$.

VIII (I982), pgs. 39-52; D.C. Schindler: "What's the Difference? On the Metaphysics of Participation in Plato, Plotinus, and Aquinas", Nova et Vetera, English Edition, V-3 (2007), pgs. 583-618; and Richard Schenk, OP: "From Providence to Grace: Thomas Aquinas and the Platonisms of the Mid-Thirteenth Century", Nova et Vetera, English Edition, III-2 (2005), pgs. 307-20.

${ }^{2}$ On natural reason as participation in the divine light, see Summa theologiae (hereafter, $S T$ ) I.I2.I I ad 3 and $S T$ I.I2.2 co. On created intellectual light as participation in uncreated light, see $S T$ I. 84.5 co. On faith as participation, see Quaestiones disputatae de veritate (hereafter, $D V$ ) I 4.2 co. On special grace as participation, see $S T$ I-2.I IO.I co. On the light of glory as participation, see $S T$ I.I2.6 co. On grace and glory as "superadded" to natural reason's participation in the divine light, see ST I.I2.2 co. and Scriptum super sententiis (hereafter, In Sent.) II.9.I.8 ad 3.

3 John Milbank and Catherine Pickstock: Truth in Aquinas, New York: Routledge 200I, pg. xiii. While Milbank and Pickstock's Truth in Aquinas is surely one of the better known attempts to locate Aquinas's account of cognition within the neo-Platonic tradition, it is not entirely unproblematic. For a critical discussion of Truth in Aquinas, see Michael WadDelL: "Faith and Reason in the Wake of Milbank and Pickstock", International Philosophical Quarterly, XLVIII-3 (September 2008), pgs. 38I-96. Other works that cast light on the neo-Platonic backdrop of Aquinas's views on cognition, even if only in passing, include Kevin Doherty, SJ: "St. Thomas and the Pseudo-Dionysian Symbol of Light", The New Scholasticism, XXXIV (April I960), pgs. I70-89; Corne- 
Milbank and Pickstock seem right to note that faith is a deeper participation in the uncreated light than natural reason, and we can broaden this observation in order to acknowledge that the light of grace is a deeper participation than the light of reason, and that the light of glory is a deeper participation than the light of grace ${ }^{4}$. While the structure of participation is a helpful way of understanding how the various modes of human cognition are related to one another-and ultimately to divine cognition-things become problematic as we ascend to the heights of human cognition in the light of glory. In Aquinas's view, the light of glory is a supernatural participation in the divine light that elevates the created intellect to a direct vision of the divine essence in the acts of rapture and the beatific vision. However, the more deeply human knowing participates in the divine light, the less clearly it remains either human or knowing. It is less clearly human because participation in the vision of the divine essence, which the light of glory makes possible, is beyond the natural capacity of any creature, including humans. And it is less clearly knowing because it is difficult to surmise how the divine essence could be in the human knower according to the mode of the knower, which would be a requirement for the existence of knowledge as Thomas typically describes it. And yet, oddly little scholarship has been produced to help

lio Fabro: "The Intensive Hermeneutics of Thomistic Philosophy: The Notion of Participation", The Review of Metaphysics, XXVII-3 (I974), pgs. 449-9I; Deborah Black: "The Influence of the De divinis nominibus on the Epistemology of St. Thomas Aquinas", Proceedings of the Patristic, Medieval and Renaissance Studies Conference, X (1985), pgs. 4I-52; and Richard Schenk, OP: "From Providence to Grace: Thomas Aquinas and the Platonisms of the Mid-Thirteenth Century", Nova et Vetera, English Edition, III-2 (2005), pgs. 307-20.

${ }^{4}$ See especially $S T$ I.I2.2 co. (quoted below). See also In II Sent. 9.I.8 ad 3: "Ad tertium dicendum, quod in homine naturalis actio nunquam potest attingere ad aequalitatem Angelorum; sed lumen gloriae superabundans omnem umbram evacuabit, non quidem tollendo naturam, sed perficiendo lumen intellectuale, quod secundum naturam in nobis defective participatur." Latin quotations from the Scriptum super Sententiis are taken from the Parma edition, I 856 (as reproduced by Busa).

Tópicos 40 (20II) 
us understand human cognition in the light of glory or the difficulties it raises.

In this essay, I will attempt to address this lacuna-or at least to begin to address it. I will begin by offering a brief sketch of the function of the lumen gloriae in Aquinas's teaching and of what is therefore at stake in the success of this doctrine (section two). Then, I will consider two of the more difficult problems that arise from Thomas's account of the light of glory, drawing on resources from Aquinas's own texts to muster responses to these problems (sections three and four).

\section{The Nature and Function of the Lumen Glo- riae}

In Summa theologiae I.I2.I, Thomas asks whether any created intellect can see the essence of God. His answer, of course, is that it can:

For as the ultimate beatitude of man consists in the use of his highest function, which is the operation of his intellect; if we suppose that the created intellect could never see God, it would either never attain to beatitude, or its beatitude would consist in something else beside God, which is opposed to faith ... Hence it must be absolutely granted that the blessed see the essence of God ${ }^{5}$.

${ }^{5} S T$ I.I2.I co.: "Cum enim ultima hominis beatitudo in altissima eius operatione consistat, quae est operatio intellectus, si nunquam essentiam Dei videre potest intellectus creatus, vel nunquam beatitudinem obtinebit, vel in alio eius beatitudo consistit quam in Deo. Quod est alienum a fide.... Unde simpliciter concedendum est quod beati Dei essentiam videant." All English quotations of the $S T$ are taken from the Summa theologiae, trans. English Dominicans, London: Burns, Oates, and Washbourne I9I2--I936, which I have emended from time to time. Latin quotations of the $S T$ are taken from the Leonine edition (Rome, I888). 
What is at stake in the rational creature's ability to know the divine essence, then, is nothing less than the very possibility of creaturely happiness.

As Thomas himself realizes, though, there is a problem that arises from the conclusion that rational creatures must be able to see the divine essence. In Summa theologiae I.I2.4, Thomas explains that:

It is impossible for any created intellect to see the essence of God by its own natural power. For knowledge is regulated according as the thing known is in the knower. But the thing known is in the knower according to the mode of the knower. Hence the knowledge of every knower is ruled according to its own nature. If therefore the mode of anything's being exceeds the mode of the knower, it must result that the knowledge of the object is above the nature of the knower .... But to God alone does it belong to be His own subsistent being . . It follows therefore that to know self-subsistent being is natural to the divine intellect alone; and this is beyond the natural power of any created intellect, for no creature is its own being, but rather it has participated being. Therefore the created intellect cannot see the essence of God, unless God by His grace unites Himself to the created intellect, as an object made intelligible to it ${ }^{6}$.

${ }^{6} S T$ I.I2.4 co.: "Impossibile est quod aliquis intellectus creatus per sua naturalia essentiam Dei videat. Cognitio enim contingit secundum quod cognitum est in cognoscente. Cognitum autem est in cognoscente secundum modum cognoscentis. Unde cuiuslibet cognoscentis cognitio est secundum modum suae naturae. Si igitur modus essendi alicuius rei cognitae excedat modum naturae cognoscentis, oportet quod cognitio illius rei sit supra naturam illius cognoscentis.... Solius autem Dei proprius modus essendi est, ut sit suum esse subsistens . ... Relinquitur ergo quod cognoscere ipsum esse subsistens, sit connaturale soli intellectui divino, et quod sit supra facultatem naturalem cuiuslibet intellectus creati: quia nulla creatura est suum esse, sed habet esse participatum. Non igitur 
Thus, while the rational creature can only find beatitude in a direct vision of the divine essence, this vision is above the creature's natural power. It is precisely to solve this problem that Thomas introduces the light of glory in his teaching. He writes:

Therefore it must be said that to see the essence of God there is required some similitude in the visual faculty, namely, the light of glory strengthening the intellect to see God, which is spoken of in the Ps. 35:IO, "In Thy light we shall see light"7.

Thomas is careful to clarify that this "similitude" consists in a likeness of the created intellect itself to the divine intellect, not in an image of the divine essence presented as an object of knowledge:

Since the intellective power of the creature is not the essence of God, it follows that it is some kind of participated likeness of Him who is the first intellect. Hence also the intellectual power of the creature is called an intelligible light, as it were, derived from the first light, whether this

potest intellectus creatus Deum per essentiam videre, nisi inquantum Deus per suam gratiam se intellectui creato coniungit, ut intelligibile ab ipso."

${ }^{7} S T$ I.I2.2 co.: "Dicendum ergo quod ad videndum Dei essentiam requiritur aliqua similitudo ex parte visivae potentiae, scilicet lumen gloriae, confortans intellectum ad videndum Deum: de quo dicitur in Psalmo: in lumine tuo videbimus lumen." While Thomas touches upon the light of glory in numerous texts, his most substantial discussions of the topic can be found in $S T$ I.I2; Summa contra gentiles (hereafter, $S c G$ ) 3.53-54; In IV Sent. 49.2.I; In IV Sent. 49.2.3; In IV Sent. 49.2.4; In IV Sent. 49.2.6; In IV Sent. 49.2.7; Super secundam Epistolam ad Corinthios lectura, ch. I2, lectio I; and Quodlibet 7.I.I. Other relevant passages include $S T$ 2-2.175.3 ad 2; $S T$ 2-2.175.4 ad 2; $D V$ 8.3 co.; $D V$ 8.3 ad 6; $D V 8.3$ ad Io; $D V$ 8.3 ad I4; $D V$ Iо.I I co.; $D V$ Io.I I ad 3; $D V$ IO.I I ad 7; $D V$ IO.I I ad I I; DV I3.2 co.; and Super evangelium Johannis ch. I, lectiones 2, 4, and 6. It is worth noting that Thomas's understanding of the nature and function of the light of glory appears to remain fundamentally the same throughout his career. 
be understood of the natural power, or of some perfection superadded of grace or of glory. Therefore, in order to see God, there must be some similitude of God on the part of the visual faculty, whereby the intellect is made capable of seeing God. But on the part of the object seen, which must necessarily be united to the seer, the essence of God cannot be seen by any created similitude ${ }^{8}$.

The light of glory, then, is a similitude comprising a supernatural perfection of the created intellectual faculty that strengthens this faculty for the vision of the divine essence. It cannot be a similitude on the part of the object seen because (as Thomas goes on to argue) every such likeness must fall short of the divine essence itself ${ }^{9}$.

${ }^{8} S T$ I.I2.2 co.: "Et cum ipsa intellectiva virtus creaturae non sit Dei essentia, relinquitur quod sit aliqua participata similitudo ipsius, qui est primus intellectus. Unde et virtus intellectualis creaturae lumen quoddam intelligibile dicitur, quasi a prima luce derivatum: sive hoc intelligatur de virtute naturali, sive de aliqua perfectione superaddita gratiae vel gloriae. Requiritur ergo ad videndum Deum aliqua Dei similitudo ex parte visivae potentiae, qua scilicet intellectus sit efficax ad videndum Deum. Sed ex parte visae rei, quam necesse est aliquo modo uniri videnti, per nullam similitudinem creatam Dei essentia videri potest."

${ }^{9}$ See ST I.I2.2 co.: "But on the part of the object seen, which must necessarily be united to the seer, the essence of God cannot be seen by any created similitude. First, because as Dionysius says (Div. Nom. i), 'by the similitudes of the inferior order of things, the superior can in no way be known;' as by the likeness of a body the essence of an incorporeal thing cannot be known. Much less therefore can the essence of God be seen by any created likeness whatever. Secondly, because the essence of God is His own very existence, as was shown above, which cannot be said of any created form; and so no created form can be the similitude representing the essence of God to the seer. Thirdly, because the divine essence is uncircumscribed, and contains in itself super-eminently whatever can be signified or understood by the created intellect. Now this cannot in any way be represented by any created likeness; for every created form is determined according to some aspect of wisdom, or of power, or of being itself, or of some like thing. Hence to say that God is seen by some similitude, is to say that the divine essence is not seen at all; which is false." / "Sed ex parte visae rei, quam necesse est aliquo modo uniri videnti, per nullam similitudinem 
This claim that, on the part of the object seen, the divine essence cannot be known by any created similitude is striking when we read it within the context of Thomas's broader theory of cognition. Thomas typically describes knowledge by saying that:

The known is a perfection of the knower, not by its substance (secundum illam rem quae cognoscitur) (for the thing is outside the knower), but rather by the likeness by which it is known; for a perfection exists in the perfected - and the likeness of the stone, not the stone, exists in the soul ${ }^{\mathrm{IO}}$.

On this account, knowledge just is the presence of the likeness (or image) of the thing known in the knower. Thomas insists, however, that this is not what happens in the direct vision of the divine essence. In Summa theologiae I.56.3 co., for example, Thomas states that a thing can be

creatam Dei essentia videri potest. Primo quidem, quia sicut dicit Dionysius, I cap. de Div. Nom., per similitudines inferioris ordinis rerum nullo modo superiora possunt cognosci: sicut per speciem corporis non potest cognosci essentia rei incorporeae. Multo igitur minus per speciem creatam quamcumque potest essentia Dei videri. - Secundo, quia essentia Dei est ipsum esse eius, ut supra ostensum est: quod nulli formae creatae competere potest. Non potest igitur aliqua forma creata esse similitudo repraesentans videnti Dei essentiam. - Tertio, quia divina essentia est aliquod incircumscriptum, continens in se supereminenter quidquid potest significari vel intelligi ab intellectu creato. Et hoc nullo modo per aliquam speciem creatam repraesentari potest: quia omnis forma creata est determinata secundum aliquam rationem vel sapientiae, vel virtutis, vel ipsius esse, vel aliquius huiusmodi. Unde dicere Deum per similitudinem videri, est dicere divinam essentiam non videri: quod est erroneum."

${ }^{10} \mathrm{DV} 2.3 \mathrm{ad}$ I: "intellectum non est perfectio intelligentis secundum illam rem quae cognoscitur, res enim illa est extra intelligentem, sed secundum rei similitudinem qua cognoscitur quia perfectio est in perfecto, lapis autem non est in anima sed similitudo lapidis." Latin quotations from $D e$ veritate are taken from the Leonine edition (Rome, I970). See also $S c G$ I.54; $S c G$ I.57; $S c G$ 4.I I; $S T$ I.I2.7 ad 3; $S T$ I.I4.I ad 3; $S T$ I.I4.I2 co.; $S T$ I.84.2 co.; $D V$ 2.5 ad I5; and especially Sentencia libri De anima (hereafter, In DA), bk. I, lect. 4, par. 43. 
known in three ways: I) by the presence of the essence in the knower, 2) by the presence of its similitude in the knower, or 3) when an image of the object is not drawn directly from the object itself but from something else in which that image appears (as, for example, when we draw a visible image of someone by seeing her reflection in the mirror) ${ }^{\mathrm{II}}$. In this text,

II See ST I.56.3 co.: "It must be borne in mind that a thing is known in three ways: first, by the presence of its essence in the knower, as light can be seen in the eye; and so we have said that an angel knows himself-secondly, by the presence of its similitude in the power which knows it, as a stone is seen by the eye from its image being in the eye- thirdly, when the image of the object known is not drawn directly from the object itself, but from something else in which it is made to appear, as when we behold a man in a mirror.

To the first-named class that knowledge of God is likened by which He is seen through His essence; and knowledge such as this cannot accrue to any creature from its natural principles, as was said above. The third class comprises the knowledge whereby we know God while we are on earth, by His likeness reflected in creatures, according to Rm. I:20: 'The invisible things of God are clearly seen, being understood by the things that are made.' Hence, too, we are said to see God in a mirror. But the knowledge, whereby according to his natural principles the angel knows God, stands midway between these two; and is likened to that knowledge whereby a thing is seen through the species abstracted from it. For since God's image is impressed on the very nature of the angel in his essence, the angel knows God in as much as he is the image of God. Yet he does not behold God's essence; because no created likeness is sufficient to represent the Divine essence. Such knowledge then approaches rather to the specular kind; because the angelic nature is itself a kind of mirror representing the Divine image." / "Considerandum est quod aliquid tripliciter cognoscitur. Uno modo, per praesentiam suae essentiae in cognoscente, sicut si lux videatur in oculo: et sic dictum est quod angelus intelligit seipsum. Alio modo, per praesentiam suae similitudinis in potentia cognoscitiva: sicut lapis videtur ab oculo per hoc quod similitudo eius resultat in oculo. Tertio modo, per hoc quod similitudo rei cognitae non accipitur immediate ab ipsa re cognita, sed a re alia, in qua resultat: sicut cum videmus hominem in speculo.

Primae igitur cognitioni assimilatur divina cognitio, qua per essentiam suam videtur. Et haec cognitio Dei non potest adesse creaturae alicui per sua naturalia, ut supra dictum est. - Tertiae autem cognitioni assimilatur cognitio qua 
Thomas makes it quite clear that the vision of the divine essence enjoyed in the light of glory occurs in the first of these ways- that is, such that the divine essence itself is in the created knower - and not in the second or third ways. Thus, when Thomas claims that no created image can produce a direct vision of the divine essence, he does not merely mean that no creature can be the object of such a vision (as in the third mode of knowing): he means that no participated likeness of the divine essence in the created intellect can suffice either (as in the second mode of knowing). Instead, as Thomas states in Summa theologiae I.I 2.5 co., the divine essence itself must become the intelligible form of the glorified intellect.

Everything which is raised up to what exceeds its nature, must be prepared by some disposition above its nature; as, for example, if air is to receive the form of fire, it must be prepared by some disposition for such a form. But when any created intellect sees the essence of God, the essence of God itself becomes the intelligible form of the intellect. Hence it is necessary that some supernatural disposition should be added to the intellect in order that it may be raised up to such a great and sublime height. Now since the natural power of the created intellect does not avail to

nos cognoscimus Deum in via, per similitudinem eius in creaturis resultantem; secundum illus Rom. I: Invisibilia Dei per ea quae facta sunt, intellecta, conspiciuntur. Unde et dicimur Deum videre in speculo. - Cognitio autem qua angelus per sua naturalia cognoscit Deum, media est inter has duas; et similatur illi cognitioni qua videtur res per speciem ab ea acceptam. Quia enim imago Dei est in ipsa natura angeli impressa per suam essentiam, angelus Deum cognoscit, inquantum est similitudo Dei. Non tamen ipsam essentiam Dei videt: quia nulla similitudo creata est sufficiens ad repraesentandam divinam essentiam. Unde magis ista cognitio tenet se cum speculari: quia et ipsa natura angelica est quoddam speculum divinam similitudinem repraesentans." Emphasis mine. See also DV 8.I ad 7; ScG 3.5I.3; and ST 3.92.I ad I5. The latter text is part of the "supplementum" of the Summa, and so cannot be taken as entirely authoritative; however, it contributes something to the evidence already available in the two other texts. 
enable it to see the essence of God, as was shown in the preceding article, it is necessary that the power of understanding should be added by divine grace. Now this increase of the intellectual powers is called the illumination of the intellect, as we also call the intelligible object itself by the name of light of illumination. And this is the light spoken of in the Apocalypse (Apoc. 2I:23): "The glory of God hath enlightened it" - viz. the society of the blessed who see God. By this light the blessed are made "deiform"-i.e. like to God, according to the saying: "When He shall appear we shall be like to Him, and we shall see Him as He is" (I Jn. 2:2) $)^{\mathrm{I} 2}$.

Without the superadded perfection of the light of glory, Thomas believes, this direct vision of the divine essence (in which the divine essence becomes the intelligible form of the created intellect) would not be possible, and thus the prospect of perfect happiness would be lost $\mathrm{t}^{\mathrm{I} 3}$.

${ }^{\mathrm{I}} S T$ I.I2.5 co.: "omne quod elevatur ad aliquid quod excedit suam naturam, oportet quod disponatur aliqua dispositione quae sit supra suam naturam: sicut, si aer deveat accipere formam ignis, oportet quod disponatur aliqua dispositione ad talem formam. Cum autem aliquis intellectus creatus videt Deum per essentiam, ipsa essentia Dei fit forma intelligibilis intellectus. Unde oportet quod aliqua dispositio supernaturalis ei superaddatur, ad hoc quod elevetur in tantam sublimitatem. Cum igitur virtus naturalis intellectus creati non sufficiat ad Dei essentiam videndam, ut ostensum est, oportet quod ex divina gratia superaccrescat ei virtus intelligendi. Et hoc augmentum virtutis intellectivae illuminationem intellectus vocamus; sicut et ipsum intelligibile vocatur lumen vel lux. Et istud est lumen de quo dicitur Apoc. XXI, quod claritas Dei illuminabit eam, scilicet societatem beatorum Deum videntium. Et secundum hoc lumen efficiuntur deiformes, idest Deo similes; secundum illud I Ioan. III: cum apparuerit, similes ei erimus, et videbimus eum sicuti est." Emphasis mine.

I3 In this regard, we can see that Thomas's teaching on the light of glory is not solely a theological matter but is also an important philosophical doctrine. Thomas believes, as a philosopher, that human happiness must be possible (or else God's creation of human nature would be in vain). And inasmuch as some-

Tópicos 40 (2OII) 
For Thomas, then, the lumen gloriae is a supernatural participation in the divine light that is gratuitously bestowed on a created intellect. The function of the lumen gloriae in Thomas's teaching is to strengthen the created intellect so that it can be elevated above its natural capacity and know the divine essence directly, making beatitude possible.

\section{OBJECTION: Wouldn't the created intellect have to become divine in order to see the divine essence directly?}

Now that we have laid out the basic elements of Thomas's teaching on the lumen gloriae, we are positioned to begin considering some objections that might be raised against $\mathrm{it}^{\mathrm{I}}{ }^{4}$. One such objection is something we might call the "apotheosis problem." We can raise this problem in the following way. According to Thomas's own argument against any creature's being able to see the divine essence by its natural powers,

knowledge is regulated according as the thing known is in the knower. But the thing known is in the knower according to the mode of the knower. Hence the knowledge of every knower is ruled according to its own nature. If therefore the mode of anything's being exceeds the mode of the knower, it must result that the knowledge of that object is above the nature of the knower.... It follows therefore that to know self-subsistent being [viz., God] is natural to the divine intellect alone; and this is beyond the natural

thing like the light of glory is required for happiness to exist, Thomas's teaching on the light of glory can be taken to be a response to a philosophical problem as well as to a theological one.

${ }^{14}$ For an interesting discussion of some related problems, approached from a different perspective, see D.C. Schindler: "Toward a Non-Possessive Concept of Knowledge: On the Relation between Reason and Love in Aquinas and Balthasar", Modern Theology, XXII-4 (October 2006), pgs. 577-607. 
power of any created intellect; for no creature is its own existence, forasmuch as its existence is participated ${ }^{\mathrm{I} 5}$.

Thus, it might seem that in order for the created intellect to know the self-subsistent divine being, the created intellect would have to undergo an apotheosis and become the divine intellect. But, of course, it is impossible for a creature to become the Creator. And therefore it might seem impossible for a human being to know the divine essence (at least directly).

At its base, this objection seems to misunderstand the relationship between nature and grace in Aquinas's teaching by failing to see that the limits of our natural human capacities are not the limits of human existence. Thomas does not say that knowledge of what exceeds our mode of being is altogether beyond us; he only says that knowledge of what exceeds the mode of the knower's being is above the nature of the knower. But the addition of grace-or, more precisely, the light of glory-to the natural light of the created intellect elevates the intellect above the limitations of its natural power so that the rational creature can know the divine essence $^{16}$. Thus, whereas the "apotheosis problem" seems to construe the natural limit of human knowing as something that cannot be transcended without rising above the level of human being, and perhaps even to construe acts that are natural only to God as being accessible only to God, Thomas seems to envision a broader spectrum of modes of being and knowing in which rational creatures can participate in what is natural to God through grace. To be sure, this participation rises above the level of what is natural to humans, but this does not mean that it rises above

\footnotetext{
${ }^{15} S T$ I.I2.4 co.: "Cognitio enim contingit secundum quod cognitum est in cognoscente. Cognitum autem est in cognoscente secundum modum cognoscentis. Unde cuiuslibet cognoscentis cognitio est secundum modum suae naturae. Si igitur modus essendi alicuius rei cognitae excedat modum naturae cognoscentis, oportet quod cognitio illius rei sit supra naturam illius cognoscentis . . Relinquitur ergo quod cognoscere ipsum esse subsistens, sit connaturale soli intellectui divino, et quod sit supra facultatem naturalem cuiuslibet intellectus creati, quia nulla creatura est suum esse, sed habet esse participatum."

${ }^{\text {I6 }}$ Recall $S T$ I.I2.4 co. and ST I.I2.5 co. Cf. ScG 3.54.I I.
} 
what is "human" altogether. The solution to the "apotheosis problem," then, would seem to lie in a clearer understanding of Thomas's teaching on the relationship between nature and grace.

As it turns out, Thomas encountered something like the "apotheosis problem" in the second objection of Summa theologiae I.I2.4. In this text, the objector argues that just as "corporeal sense cannot be raised up to understand incorporeal substance, which is above its nature," so too "no created intellect can reach up to see the essence of God at all" "if to see the essence of God is above the nature of every created intellect." ${ }^{17}$ Against this objection, Thomas argues:

The sense of sight, as being altogether material, cannot be raised up to immateriality. But our intellect, or the angelic intellect, inasmuch as it is elevated above matter in its own nature, can be raised up above its own nature to a higher level by grace. The proof is that sight cannot in any way know abstractedly what it knows concretely; for in no way can it perceive a nature except as this one particular nature; whereas our intellect is able to consider abstractedly what it knows concretely. Now although it knows things that have a form residing in matter, still it resolves the composite into both of these elements; and it considers the form separately by itself. Likewise, also, the intellect of an angel, although it naturally knows the concrete in any nature, still it is able to separate that existence by its intellect since it knows that the thing itself is one thing and its existence is another. Since therefore the created intellect is naturally capable of apprehending concrete form and the concrete being in abstraction, through a kind of resolution of parts,

${ }^{17} S T$ I.I2.4 obj. 3: "sensus corporeus non potest elevari ad intelligendam substantiam incorpoream, quia est supra eius naturam. Si igitur videre Deum per essentiam sit supra naturam cuiuslibet intellectus creati, videtur quod nullus intellectus creatus ad videndum Dei essentiam pertingere possit ...” 
it can by grace be raised up to know separate subsisting substance, and separate subsisting existence ${ }^{\mathrm{I} 8}$.

In this passage, Thomas clearly maintains that grace can elevate the human intellect above its natural capacity and that there is nothing that prevents the human intellect from knowing subsisting existence-that is, the divine essence-when it is elevated in this manner. What is more, the human intellect need not become divine to know the divine essence: it only needs to be elevated above the natural human mode of existence to the mode of existence humans enjoy in the light of glory.

But Thomas's arguments for these claims reveal a much richer understanding of the relationship between natural knowing and glorified knowing than we have yet proposed. Thomas seems to be suggesting that the natural acts of abstraction and separation-by which, respectively, we come to know forms apart from matter and "being" as distinct from the things that have being-are intimations of an (obediential) potentiality to know separate subsistent being that can be realized in the light of glory $^{19}$. It is as though Thomas finds the seeds of glorified knowing lying dormant in natural acts of knowing. In this way, Thomas's teaching on

\footnotetext{
${ }^{18}$ ST I.I2.4 ad 3: "sensus visus, quia omnino materialis est, nullo modo elevari potest ad aliquid immateriale. Sed intellectus noster vel angelicus, quia secundum naturam a materia aliqualiter elevatus est, potest ultra suam naturam per gratiam ad aliquid altius elevari. Et huius signum est, quia visus nullo modo potest in abstractione cognoscere id quod in concretione cognoscit, nullo enim modo potest percipere naturam, nisi ut hanc. Sed intellectus noster potest in abstractione considerare quod in concretione cognoscit. Etsi enim cognoscat res habentes formam in materia, tamen resolvit compositum in utrumque, et considerat ipsam formam per se. Et similiter intellectus Angeli, licet connaturale sit ei cognoscere esse concretum in aliqua natura, tamen potest ipsum esse secernere per intellectum, dum cognoscit quod aliud est ipse, et aliud est suum esse. Et ideo, cum intellectus creatus per suam naturam natus sit apprehendere formam concretam et esse concretum in abstractione, per modum resolutionis cuiusdam, potest per gratiam elevari ut cognoscat substantiam separatam subsistentem, et esse separatum subsistens."

${ }^{19}$ For more on the acts of abstraction and separation, see Aquinas's Super Boetium de Trinitate q. 5, a. 3 .
}

Tópicos 40 (2OII) 
acts of abstraction and separation and their relationship to knowing in the light of glory speaks to the broader issue of the relationship between nature and grace, and suggests a deep continuity of the natural and the graced rather than a bifurcation of them.

The terminology and analogies Thomas uses to explain the manner in which the light of glory perfects the human intellect are also telling in this regard. Thomas consistently writes of the lumen gloriae "raising," "elevating" and "strengthening" the intellect ${ }^{20}$. His diction does not suggest a radical break between the natural acts of the created intellect and its acts in the state of glory, but rather a continuity. Thomas even states that:

The created light is necessary to see the essence of God, not in order to make the essence of God intelligible, which is of itself intelligible, but in order that the intellect might become [more] capable (potens) of understanding in the same way as, through a habit, a potentiality becomes more capable (potentior) of operating ${ }^{2 \mathrm{I}}$.

The analogy to the way in which a habit makes a power more able to act and the way in which the light of glory elevates the intellect beyond its natural capacity suggests that there is some kind of capacity or obediential potentiality for the created intellect to be actualized by a vision of the divine essence already extant at the natural level_-bearing in mind, of course, that this potency cannot be actualized either by the created intellect itself or even by the divine essence considered as intelligible form but only by a supernatural disposition that prepares the created intellect to receive the divine essence as a form joined to it as an object of knowledge $^{22}$. Thus, while the light of glory is a gift that makes the created

${ }^{20}$ See, for example, ST I.I2.4 ad 3 and ST I.I2.5 ad 2.

${ }^{21} S T$ I.I2.5 ad I: "Iumen creatum est necessarium ad videndum Dei essentiam, non quod per hoc lumen Dei essentia intelligibilis fiat, quae secundum se intelligibilis est, sed ad hoc quod intellectus fiat potens ad intelligendum, per modum quo potentia fit potentior ad operandum per habitum."

${ }^{22}$ I invoke here Thomas's distinction between a "natural potency" and an "obediential potency" (e.g., DV 8.4 ad I3) in hopes of avoiding misunderstand- 
ings of the suggestion that human beings might have a potency for seeing God. As Thomas suggests in Summa contra Gentiles 3.53.3, the created intellect must be elevated by "a more sublime disposition" even to the capacity for being joined to the divine essence as an object of knowledge. Moreover, this disposition cannot be construed merely as an intensification of the natural power of the created intellect-if by "intensification" we mean an addition that does not rise above the level of the rational creature's natural powers - but might instead be construed more like a new form that strengthens its recipient (see $S c G$ 3.53.5). To illustrate this manner of strengthening something's power, Thomas explains that "the power of a diaphanous object is increased so that it can shine with light, by virtue of its becoming actually luminous, through the form of light received for the first time within it." (ScG 3.53.5) And yet, it seems to me that just as an object cannot become luminous unless it is diaphanous in the first place (see ScG 3.53.2), so too there must already be present in the created intellect some sort of potentiality for the "new form" of the lumen gloriae, before the light of glory is given, in order for the created intellect to receive the disposition of the lumen gloriae in the first place. Thus, the kind of strengthening we are talking about is not merely an intensification of the natural powers, but neither is it the introduction of a capacity completely foreign to the natural being and acts of the rational creature. Because glory perfects nature rather than destroying it, the light of glory must somehow perfect a potency that existed at the level of nature but can only be actualized by grace. I use the term "obediential potency" in an attempt to capture this duality, namely, that there is something in human nature that makes it possible for us to be elevated by the light of glory to see the divine essence (which would not be true, say, for an inanimate being) and the fact that it is only through God's gift of the light of glory that human nature can be elevated in this way (which would not be true, say, for the human potential to know material beings).

Interestingly, Thomas himself often describes the soul as having a natural "capacity" (capax) for seeing God (and, more broadly, for being united with God through the soul's faculties of intellect and will). For Thomas's decisive assertion that "homo est capax visionis divinae essentiae," see ST I-2.5. I co. For his usage of the term capax to describe human nature's disposition toward the visio beata, see ST 3.9.2 ad 3. For Thomas's attribution of a capax dei to human nature, see $S T$ 3.4.I ad 2 and ST I-2.I I3. IO co; and for his attribution of a capax dei to the human soul, see, for example, ST 3.6.2 co.; DV 22.2 ad 5; and In I Sent. 37.2.3 expositio textus. Finally, Thomas attributes a capax perfecti boni to the human being (homo) at ST I-2.5.I co.

Tópicos 40 (2OII) 
intellect capable of operations of which it would not be capable if it were left merely to its natural powers, there is still a continuity between the rational creature's natural powers and its vision of the divine essence in the light of glory. To use Thomas's own words: "glory perfects nature, it does not destroy it." 23

We can see, then, that the assumption of the "apotheosis problem"-namely, that the human intellect cannot rise above its natural capacity without ceasing to be human-simply does not hold true within Thomas's understanding of the relationship between nature and grace. The limits of our natural capacity for knowing are not the limits of all human knowing whatsoever. Neither must we become divine in order to participate in the vision of the divine essence that is natural to God: for God's knowing, like God's being, is self-subsistent, whereas the knowledge of the divine essence we receive in the light of glory is obtained through participation. Thus, when the light of glory elevates the human intellect beyond its natural capacity, human nature is not destroyed or replaced with divine nature. Instead, the light of glory perfects the power that is seminally present in the created intellect's natural capacity to look upon abstracted forms and separated being, and enables the created intellect to participate in an act that is essential to the divine intellect.

\section{OBJECTION: How can the divine essence be "in" the intellect of a created knower?}

Even if one concedes that the created intellect can be elevated beyond the limitations of its nature and know something above its own mode of being with the help of grace, though, there would seem to be peculiar problems that arise from the prospect of knowing the divine essence. And these problems are not obviously solved by invoking the power of grace to strengthen the light of the created intellect. For example, according to Thomas's own recurring description of knowledge,

${ }^{23}$ See In IV Sent. 49.2.3 ad 8: "gloria perficit naturam, et non destruit." See also $D V 8.5$ ad 3 and $D V 9.3$ ad 2. 
the thing known must be in the knower according to the mode of the knower ${ }^{24}$. At the same time, Thomas maintains that the divine essence itself is in the glorified intellect as its intelligible form ${ }^{25}$. But how can what is infinite be in what is finite? Or how can esse per se subsistens be in what has esse only per participationem? ${ }^{26}$ In other words, how can the divine essence be in the created knower according to the mode of the knower - not as a finite, participated image, but in such a way that the divine essence itself is the intelligible form of the intellect? ${ }^{27}$

There are at least two ways in which we might approach this problem, namely, by considering what it is to be "in the knower" in the light of glory and by considering what the "mode of the knower" is in the light of glory. For if either of these differs significantly from how we know them in via, then what it means to be "in the knower according to the mode of the knower" under the light of glory might also be different enough

\footnotetext{
${ }^{24}$ See, for example, $S T$ I.I2.4 co.

${ }^{25}$ See $S T$ I.I 2.5 co.

${ }^{26}$ Thomas notes that philosophers and theologians alike have had difficulty understanding how a created intellect can look upon the uncreated divine essence at In IV Sent 49.2.I co.: "et ideo circa hanc quaestionem eadem difficultas et diversitas invenitur apud philosophos et apud theologos. Quidam enim philosophi posuerunt quod intellectus noster possibilis nunquam potest ad hoc pervenire ut intelligat substantias separatas, sicut Alpharabius in fine suae Ethicae: quamvis contrarium dixerit in Lib. de intellectu, ut Commentator refert in 3 de anima. Et similiter quidam theologi posuerunt, quod intellectus humanus nunquam potest ad hoc pervenire quod Deum per essentiam videat. Et utrosque ad hoc movet distantia inter intellectum nostrum et essentiam divinam, vel alias substantias separatas. Cum enim intellectus in actu sit quodammodo unum cum intelligibili in actu, videtur difficile quod intellectus creatus aliquo modo fiat essentia increata; unde et Chrysostomus dicit: quomodo enim creabile videt increabile?"

${ }^{27}$ Thomas himself acknowledges the force of this difficulty at In IV Sent 49.2.I co. While he continues to insist that the divine essence can not be seen by a created intellect in the manner of an impressed species but must rather be united directly to the created intellect as its form, Thomas never clarifies how the divine essence can still be said to be "in the knower according to the mode of the knower."
}

Tópicos 40 (20II) 
to resolve our problem. As I will argue, there are significant differences to be found on both counts, though the differences in what it means to be "in the knower" are perhaps most decisive.

Let me begin by considering the mode of the knower under the influence of the light of glory. In Summa theologiae I.I2.6 co., while addressing the question of whether one person can see the essence of God more perfectly than another, Thomas makes an intriguing statement about the relationship between charity and the lumen gloriae:

Of those who see the essence of God, one sees Him more perfectly than another. This, indeed, does not take place as if one had a more perfect similitude of God than another, since that vision will not spring from any similitude; but it will take place because one intellect will have a greater power or faculty to see God than another. The faculty of seeing God, however, does not belong to the created intellect naturally, but is given to it by the light of glory, which establishes the intellect in a kind of "deiformity" ...

Hence the intellect that has more of the light of glory will see God the more perfectly; and he will have a fuller participation of the light of glory who has more charity; because where there is the greater charity, there is the more desire; and desire in a certain degree makes the one desiring apt and prepared to receive the object desired. Hence he who possesses the more charity, will see God the more perfectly, and will be the more beatified ${ }^{28}$.

${ }^{28}$ ST I.I2.6 co.: "Videntium Deum per essentiam unus alio perfectius eum videbit. Quod quidem non erit per aliquam Dei similitudinem perfectiorem in uno quam in alio: cum illa visio non sit futura per aliquam similitudinem, ut ostensum est. Sed hoc erit per hoc, quod intellectus unius habebit maiorem virtutem seu facultatem ad videndum Deum, quam alterius. Facultas autem videndi Deum non competit intellectui creato secundum suam naturam, sed per lumen gloriae, quod intellectum in quadam deiformitate constituit .... Unde intellectus plus participans de lumine gloriae, perfectius Deum videbit. Plus autem partic- 
What is striking about this passage is the way in which charity comes to bear upon the intellect's reception of the lumen gloriae, and therefore also bears upon the perfection with which the intellect sees the divine essence. Thomas indicates that charity, which is a virtue of the will, determines the extent to which the intellect shall participate in the light of glory (which Thomas elsewhere describes as a kind of habit perfecting the intellect). In other words, the virtue of the will flowers into the perfection of the intellect. Thus, it seems that the separation of intellect and will (and therefore the separation of knowledge and love) that we experience in via might be diminished in the perfection of the lumen gloriae-or, at the very least, that this separation does not abide in the way we know it in the natural mode of the soul.

This suggestion that the intellect and will might become more unified in the light of glory seems to be in keeping with other aspects of Aquinas's thought. In God, for example, will and intellect are both identical with the divine essence ${ }^{29}$. So, inasmuch as the rational creature participates in God more perfectly through the light of glory, it would make sense that the glorified soul would also be elevated toward a greater unity of faculties. Moreover, the basic logic of transcendental unity suggests that the more perfectly something has being, the more perfectly one it should become ${ }^{30}$. Thus, it seems plausible that the rational creature, elevated to its highest level of perfection through the lumen gloriae-indeed, participating in God's own vision of Godself-should also be healed of the fragmentation of intellect and will that we experience as natural in via and would thereby enjoy a more perfectly unified mode of being.

To appreciate the significance of this deeper unity of intellect and will in glory, we must recall that, for Thomas, the usual act of the (speculative) intellect consists in the idea of the thing understood existing in the

\footnotetext{
ipabit de lumine gloriae, qui plus habet de caritate: quia ubi est maior caritas, ibi est maius desiderium; et desiderium quodammodo facit desiderantem aptum et paratum ad susceptionem desiderati. Unde qui plus habebit de caritate, perfectius Deum videbit, et beatior erit."

${ }^{29}$ See, for example, $S c G$ I.45 and $S c G$ I.73.

${ }^{30}$ See, for example, $S T$ I.I I.I co. and $D V$ I.I co.
} 
one who understands, whereas the act of the will is inclined toward the object as it exists in itself ${ }^{3 \mathrm{I}}$. In other words, the act of the intellect seems to be primarily receptive of an image whereas the act of the will seems to reach outward toward the substance of what is desired. Now, if the separation of intellect from will is overcome (or at least diminished) in the light of glory, then the bifurcation of the soul's receptivity in knowing and its turning outward in loving should also be overcome (or at least diminished), so that receiving would extend into giving and these two acts would tend toward becoming one ${ }^{32}$. Thus, knowing would extend beyond itself in patria, as willing does in via. This means that the soul's glorified act of knowing would not be limited by what the soul can contain (or receive) but would also extend into what the soul tends toward outside of itself.

What this suggests for the problem at hand is that the mode of the knower perfected by the light of glory might be significantly different from the natural mode of the knower. As we noted above, in the natural mode of knowledge, the knower is indeed perfected by an image of the thing known that exists in the knower ${ }^{33}$. When it is elevated by the light of glory, though, the intellect might be perfected by the thing known as it exists in itself and according to its own being outside of the soul. Thus, even if the created intellect cannot contain the divine essence, this might not prevent the glorified intellect from knowing the divine essence because the act of the glorified intellect might reach outward toward the divine essence as it exists in itself-as the will does in via-and there-

\footnotetext{
${ }^{3 \mathrm{I}}$ See $S T$ I.82.3 co.; $S T$ I.I6.I co.; and $S T$ I.27.4 co.

${ }^{32}$ For additional discussion of the relationship between intellect and will, or cognitive and affective activity, at the highest levels of knowing-including the light of glory and the beatific vision-see Jean-Pierre Torrell, OP: "Thomas Aquinas: Theologian and Mystic", Nova et Vetera, English Edition, IV-I (2006), pgs. I-I6, esp. pgs. 7-II; idem, St. Thomas Aquinas: Volume Two: Spiritual Master (hereafter, Spiritual Master), trans. Royal, Washington, D.C.: Catholic University of America Press 2003, esp. pgs. 95-99.

${ }^{33}$ Recall $D V$ 2.3 ad I; ScG I.54; ScG I.57; ScG 4.I I; ST I.I2.7 ad 3; ST I.I 4.I ad 3; ST I.I4.I 2 co.; $S T$ I.84.2 co.; $D V 2.5$ ad I 5; and In $D A$, bk. I, lect. 4, par. 43 .
} 
fore the perfection of the intellect would not be limited by a participated likeness of the divine essence existing in the created intellect. In this way, the mode of knowing that we typically enjoy in via would be transcended, and the knower would be perfected by the very being of the thing known and not merely by its image.

This first suggestion, then, attempts to explain how a created intellect can know the divine essence directly by reconsidering what the mode of the knower is in the light of glory. But even if this proposal offers a way in which the created intellect could encounter the divine essence itself and not merely an image of that essence, it is still not clear how the divine essence could be said to be "in" the knower as its intelligible form-and thus how it could be said to be "known"- on this account. And this is precisely what Thomas says happens when the light of glory elevates the created intellect to a direct vision of the divine essence ${ }^{34}$. So, even if we accept the notion that the glorified intellect can be perfected in its knowledge by something outside itself and not merely by an image of that thing found in the intellect, we would have to acknowledge that we are using the term "knowledge" in a very different way from how we normally apply it to human knowing. This extended sense of the term might simply be analogous rather than equivocal, but, in any case, it is very different from what Thomas usually means when he writes about (natural) human knowledge-so much so that one might wonder whether it could still legitimately be construed as "knowing."

To make greater progress toward resolving this problem, we must now turn to the possibility that what it means for something to be "in the knower" under the influence of the light of glory might be significantly different from what it means to be "in the knower" in via. Let me suggest that our exploration of this possibility might be facilitated by considering the ways in which God can be said to be "in" creatures. In Summa theologiae I.8.I co., Thomas explains that:

God is in all things; not, indeed, as part of their essence, nor as an accident, but as an agent is present to that in which

\footnotetext{
${ }^{34}$ Recall ST I.I2.4 co. and I.I2.5 co.
} 
it acts. For an agent must be joined to that wherein it acts immediately and touch it by its power; hence it is proved in Phys. vii that the thing moved and the mover must be joined together. Now since God is being itself by His own essence, created being must be His proper effect, as to ignite is the proper effect of fire. Now God causes this effect in things not only when they first begin to be, but as long as they are preserved in being, as light is caused in the air by the sun as long as the air remains illuminated. Therefore as long as a thing has being, God must be present to it, according to its mode of being. But being is innermost in each thing and most fundamentally inherent in all things since it is formal in respect of everything found in a thing, as was shown above. Hence it must be that God is in all things, and intimately $\mathrm{so}^{35}$.

In this passage, Thomas is, of course, merely considering the way in which God can be said to be in creatures in general, namely, as a cause (or agent) is said to be in its effect. But Thomas's comments here also point us in the direction of an answer to the more specific problem of how the divine essence can be said to be "in" the glorified created intellect as its intelligible form. In particular, Thomas notes that God can be said to be

${ }^{35} S T$ I.8. I co.: "Deus est in omnibus rebus, non quidem sicut pars essentiae, vel sicut accidens, sed sicut agens adest ei in quod agit. Oportet enim omne agens coniungi ei in quod immediate agit, et sua virtute illud contingere: unde in VII Physic. probatur quod motum et movens oportet esse simul. Cum autem Deus sit ipsum esse per suam essentiam, oportet quod esse creatum sit proprius effectus eius; sicut ignire est proprius effectus ignis. Hunc autem effectum causat Deus in rebus, non solum quando primo esse incipiunt, sed quandiu in esse conservantur; sicut lumen causatur in aere a sole quandiu aer illuminatus manet. Quandiu igitur res habet esse, tandiu oportet quod Deus adsit ei, secundum modum quo esse habet. Esse autem est illud quod est magis intimum cuilibet, et quod profundius omnibus inest: cum sit formale respectu omnium quae in re sunt, ut ex supra dictis patet. Unde oportet quod Deus sit in omnibus rebus, et intime." 
in all things "intimately" inasmuch as God is Essential Being and being is "formal in respect of everything found in a thing." This suggests that God is especially said to be "in" creatures by virtue of standing in relation to them as a formal principle. Now, as Thomas adds in his response to the second objection of Summa theologiae I.8.I:

Although corporeal things are said to be in another as in that which contains them, nevertheless, spiritual things contain those things in which they are; as the soul contains the body. Hence also God is in things containing them; nevertheless, by a certain similitude to corporeal things, it is said that all things are in God; inasmuch as they are contained by $\mathrm{Him}^{36}$.

In this intriguing passage, Thomas suggests that while spiritual things are said to be "in" other things, they are nevertheless in them in such a way that the spiritual things contain the things in which they are. We might debate whether this principle pertains to the relationship between form and matter in general-as, for example, in the way formal likenesses of material beings exist in our intellects-but it surely seems to apply to cases where a spiritual being is related to something else as its formal principle. And this is precisely what Thomas has asserted to be the case when the divine essence is in the created intellect strengthened by the light of glory: the divine essence becomes the intelligible form of the rational creature ${ }^{37}$. Thus, rather than the created intellect having to contain the

\footnotetext{
${ }^{36} S T$ I.8. I ad 2.: "Licet corporalia dicantur esse in aliquo sicut in continente, tamen spiritualia continent ea in quibus sunt, sicut anima continet corpus. Unde et Deus est in rebus sicut continens res. Tamen, per quandam similitudinem corporalium, dicuntur omnia esse in Deo, inquantum continentur ab ipso." Emphasis mine.

${ }^{37}$ Hence, if it is not problematic for us to say that the soul is in the body, even though the soul is ontologically greater than the body, neither should it be a problem to say that God is in the rational creature. In fact, inasmuch as the divine essence is related to the glorified intellect as its intelligible form, the analogy to the way in which the soul is in the body — viz., as a form is in matter-is
} 
divine essence as something known-which happens, for example, when the created intellect knows forms abstracted from material beings- the rational creature is actually contained by God when it knows the divine essence in glory ${ }^{38}$. So, saying that God is "in" the created intellect is really tantamount to saying that the created intellect is "in" God ${ }^{39}$. Accordingly, the fact that the created intellect is finite and cannot exhaustively contain the divine essence need not pose a problem: for the divine essence can be said to be "in" the glorified knower as something containing it rather than as something contained by it. And this might well be just what it means for the divine essence to be "in" the human knower in the state of glory.

\section{Conclusion}

By way of conclusion, then, let me rehearse a few points. Thomas's teaching on the lumen gloriae is worthy of attention because it is a critical component of his broader doctrine about happiness, the beatific vision, and the very purpose of human existence-not to mention the fact that it

somewhat instructive. For Thomas suggests in ST I.7.I co. and I.I4.I co. that form is contracted by matter, and in $S T$ I.7.I he draws a parallel between the infinity and perfection of form and the infinity and perfection of God. Moreover, Thomas describes the relationship between God and the beatified created intellect precisely in terms of the relationship between form and matter at In $I V$ Sent. 49.2.I co. It is important to note that we are not claiming here that God is the substantial form (or the form secundum esse naturale) of the beatified created intellect, which is impossible (see $S c G$ I.26-I.27), but only that God is its form in the sense of being its intelligible species, which is not possible (see $S c G$ 3.5I.3-3.5I.4).

${ }^{38} \mathrm{This}$ is, of course, perfectly consistent with Thomas's steadfast insistence that no creature can know the divine essence comprehensively (e.g., ST I.I2.7 co. and $S c G$ 3.55).

${ }^{39}$ Thus, we might just as well say that the created intellect is "in" God as that God is "in" the created intellect, as both Augustine and Anselm do. See, for example, Augustine's Confessions I.ii.2 and De trinitate I3.I2, as well as Anselm’s Proslogion I9. Cf. Torrell, Spiritual Master, pgs. 68-69. 
is the summit of his account of human cognition. Since Thomas's teaching about the light of glory is somewhat less clear than I suspect the light of glory itself will be, there is work to be done in sorting out some of the problems that arise within this teaching. Among these problems are difficulties concerning the question of how our knowing the divine essence directly in the light of glory can remain a human act of knowledge. Given Thomas's general principle that no intellect can know any thing that exceeds its own mode of being, it is difficult to envision how a human being can know the divine essence while still remaining human. What is more, since Thomas normally understands knowledge to be the presence of the thing known in the knower according to the mode of the knower, it is difficult to see how God, Who is Infinite, Essential Being, can be known by —and thus can be "in"—any finite, participated being. I believe that Thomas's own writings provide resources for solving these problems surrounding his teaching on the light of glory; but it is still important that we acknowledge and address the problems, as I hope to have done in this essay. 